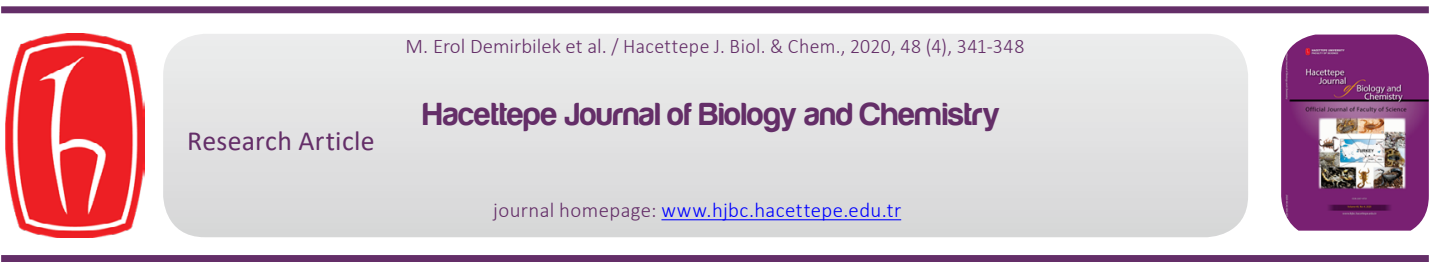

\title{
Effects of Bacterial Phbv-Conduit Used for Nerve Regeneration on Oxidative Stress Parameters in Rats
}

\section{Ratlarda Sinir Rejenerasyonu için Kullanilan Bakteriyel Phbv-Kondüitin Oksidatif Stress Parametreleri Üzerine Etkisi}

\author{
Melike Erol-Demirbilek ${ }^{1 \odot}$, Murat Demirbilek ${ }^{2}$, Ebru Erdal ${ }^{3}{ }^{\circledR}$, Mustafa Sakar ${ }^{\circ}$ and Gokhan Bozkurt $^{5}$ \\ ${ }_{1}^{1}$ Biotechnology Research Center, Republic of Turkey Ministry of Food Agriculture and Livestock, Ankara, Turkey. \\ ${ }^{2}$ Advanced Technologies Research and Application Center, Hacettepe University, Ankara, Turkey. \\ ${ }^{3}$ Faculty of Medicine, Yıldırım Beyazıt University, Ankara, Turkey. \\ ${ }^{4}$ Institute of Neurological Sciences, Başıbüyük Campus, Marmara University, İstanbul, Turkey. \\ ${ }^{5}$ Department of Neurosurgery, Memorial Bahçelievler Hospital,, Istanbul Turkey.
}

\section{ABSTRACT}

\begin{abstract}
ue to lack of self-repair mechanism in neuronal tissue, biomaterials have been widely studied to regenerate damaged nerve tissue. Despite having advantages, nano materials may cause oxidative stress and this could affect the treatment. In the present study, whether PHBV [poly (3-hydroxybutyrate-co-3-hydroxyvalerate)] used for axonal regeneration could lead to lipid peroxidation, protein oxidation in rats or not and also its effects on antioxidant molecules was explored. In the study, PHBV nanofiber membranes were formed by electrospinning and conduits were formed by using the nanofiber membrane. After the formation of a $1 \mathrm{~cm}$ gap in the rat peritoneal nerves, PHBV conduits were placed. Animals were sacrificed at 17th week after the operations. Malondialdehyde (MDA), advanced oxidation protein products (AOPP), glutathione (GSH) levels and superoxide dismutase (SOD) activities of livers, as well as surrounding tissues of conduits (muscles) and serums were measured. Compared to control groups, MDA, AOPP and GSH levels and SOD activites in all graft group serums showed a significant increase, while only MDA and AOPP levels in tissues were statistically higher. Therefore, these findings suggest that PHBV nerve graft used for sciatic nerve defects may lead to oxidative stress in rats.
\end{abstract}

\section{Key Words}

Poly-(3-hydroxybutyrate-co-3-hydroxyvalerate) graft, oxidative stress parameters

\section{öz}

Öronal hücrelerin kendi kendilerini tamir mekanizmaları olmamasından dolayı, hasarlı sinir dokularının rejenerasyonunda biyomateryaller yaygın bir şekilde çalışı mıştır. Avantajları olmasına rağmen, nanomateryaller oksidatif strese neden olabilir ve bu durum tedaviyi etkileyebilir. Bu çalışmada, aksonal rejenerasyon için kullanılan PHBV [poly (3-hydroxybutyrateco-3-hydroxyvalerate)]'nin ratlarda lipid peroksidasyonuna ve protein oksidayonuna neden olup olmadığı ve ayrıca antioksidan molekülleri etkileyip etkilemediği araştırıldı. Çalışmada, elektrospinning ile PHBV yönlendirilmiş nanofiber membranlar hazırlandı ve bunlar kullanılarak graftler oluşturuldu. Sıçan peritoneal sinirlerinde $1 \mathrm{~cm}$ boşluk oluşturulduktan sonra PHBV graftler yerleştirildi. Hayvanlar operasyon sonrası 17. haftada feda edildi. Ratların kan, karaciğer ve graft yerleştirilen perioneal sinir demeti çevre kas dokusu malondialdehit (MDA), ileri oksidasyon protein ürünleri (AOPP), glutatyon (GSH) seviyeleri ve süperoksit dismutaz (SOD) aktiviteleri ölçüldü. Kontrol grubu ile karşılaştırıldığında, tüm graft grubu serum MDA, AOPP ve GSH düzeyleri ve SOD aktivitelerinde anlamlı bir artış gözlenirken, dokularda sadece MDA ve AOPP seviyeleri istatistiksel olarak yüksek bulundu. Bu bulgular perioneal sinir defektleri için kullanılan PHBV graftinin sıçanlarda oksidatif strese neden olabileceğini düşündürmektedir.

\section{Anahtar Kelimeler}

Poli- (3-hidroksibütirat-ko-3-hidroksivalerat) graft, oksidatif stres parametreleri

Article History: Received: Sep 10, 2019; Revised: jun 4, 2020; Accepted: Jun 11, 2020; Available Online: Sep $28,2020$. DOI: https://doi.org/10.15671/hjbc.617783

Correspondence to: M. Erol-Demirbilek, Biotechnology Res. Center, Republic of Turkey Ministry of Food Agriculture and Livestock, Ankara, Turkey. E-Mail: melikerol@yahoo.com 


\section{INTRODUCTION}

Damaged nerve tissue lack self-repair mechanisms for structural and functional redintegration [1]. Aligned polymeric conduits are considered as promising materials being an alternative to autologous nerve grafts in neural tissue engineering. Biocompatibility, biodegradability and stimulate axonal regeneration are the three characteristics for an ideal polymer nerve conduit. As biomaterial-induced oxidative stress can be regarded as one of the cause of implant failure. Therefore, there is a need for detailed characterization study of biomaterials. In this regard, the effect of PHBV nanofiber conduit on cellular oxidative stress was investigated.

The imbalance between the oxidant and antioxidant systems, if in favor of the oxidants, leads to oxidative stress influencing the activation of apoptosis, ion transport, calcium mobilization and excitotoxicity and therefore this condition in turn leads to cellular death [2]. Malondialdehyde (MDA) is a lipid peroxidation biomarker correlated with oxidative stress [3]. Along with this, advanced oxidation protein products (AOPP) are dityrosine-containing and cross-linking protein products which are constituted by reaction of plasma protein with chlorinated oxidants in the process of oxidative stress. Therefore, AOPP are considered as the markers of oxidant-mediated protein damage [4]. Glutathione (GSH; $\mathrm{Y}$-L-glutamyl-L-cysteinylglycine) is the required molecule in regulating the thiol-redox status and reducing the ROS production in neuronal cells [5]. Glutathione redox system is regarded as the main component of all cells to maintain antioxidant defence capacity. GSH for the sake of its chemical structure scavenges free radicals and reactive oxygen species effectively. In this process, Superoxide dismutase (SOD) which is a primary endogenous cellular defense system against oxidative stress catalyzes the dismutation of superoxide radical $\left(\mathrm{O}_{2}{ }^{\circ}\right)$ to hydrogen peroxide $\left(\mathrm{H}_{2} \mathrm{O}_{2}\right)$ and molecular oxygen $\left(\mathrm{O}_{2}\right)$. Meanwhile, it protects the neurons from hydrogen peroxide $\left(\mathrm{H}_{2} \mathrm{O}_{2}\right)$-induced oxidative stress effectively and inhibits the apoptotic cell death [6].

The relationship between oxidative stress and inflammation, cancer, aging, cardiological and neurological diseases is known and oxidative stress could occur at all stage of wound healing after biomaterial implantation [7]. Essentially, physical and chemical properties of a material affects oxidative stress. Metallic nanoparticles are known to cause ROS [8]. But, there are limited studi- es on the effect of nanofiber materials on ROS metabolism in the literature. For example, Hsiao-Hua Chang et al. reported that 2-Hydroxy-ethyl methacrylate increases the ROS level in dental gingival epithelial cells. [9]. Wei-Wu Jiang et al. found that poly-L-glycolic acid (PLLA) degradation products in mice increased phagocytic activity and increased superoxide dismutase activity [10]. Wendy F. Liu et al. showed that the polystyrene increases the level of ROS more than alginate [11].

PHBV is a polyester and one of the bacterial biopolymer. In our previous study, PHBV nanofiber conduit was formed and efficiancy on rat perieonal nerve regeneration was evaluatted [12]. In this study PHBV conduit used for perioneal nerve regeneration with respect to ROS formation and antioxidant status was evaluated. To investigate PHBV-conduit-induced oxidative stress, the endproducts of lipid peroxidation (MDA) and protein oxidation (AOPP) and some antioxidant molecules (GSH, SOD) levels were measured in surrounding tissues of conduits (muscles), livers and blood samples.

\section{MATERIALS and METHODS}

Trichloroacetic acid (TCA), chloramine T, potassium iodide, acetic acid, $L$ xanthine, nitro blue tetrazolium (NBT), $\mathrm{Na}_{2} \mathrm{CO}_{3}$, bovine serum albumine (BSA), xanthine oxidase, $\mathrm{CuCl}_{2}$, 5,5'-ditiyo-bis-2-nitrobenzoic acid, Tris-EDTA, 2-Thiobarbituric acid (TBA), n-butanol were purchased from Sigma (USA).

\section{Animal Study}

Twenty-four female Sprague-Dawley rats weighing approximately $250 \mathrm{~g}$ provided by Hacettepe University Animal Laboratory, Ankara, Turkey were used in the study. All procedures involving animals were performed in accordance with "Animals Committee of Hacettepe University". Rats were randomly divided into two experimental groups, PHBV conduit group $(n=12)$ and control group $(n=12)$. Then, the rats were anesthetized by intraperitoneal injection of ketamine-xylazine (ketamine $5 \%, 100 \mathrm{mg} / \mathrm{kg}$ and xylazine $2 \%, 5 \mathrm{mg} / \mathrm{kg}$ ) and right sciatic nerve of each animal was exposed (Figure 1A) and finally $10 \mathrm{~mm}$ nerve gap was formed. In PHBVconduit group, PHBV conduits were placed in right perioneal nerve of rats (Figure $1 \mathrm{~B}$ ). Control group was not subjected to any of PHBV graft treatments. The animals were kept in 12/12 h light/dark cycle rooms and housed, fed routinely, and monitored for changes in their ordinary conditions and motor activities. They finally 

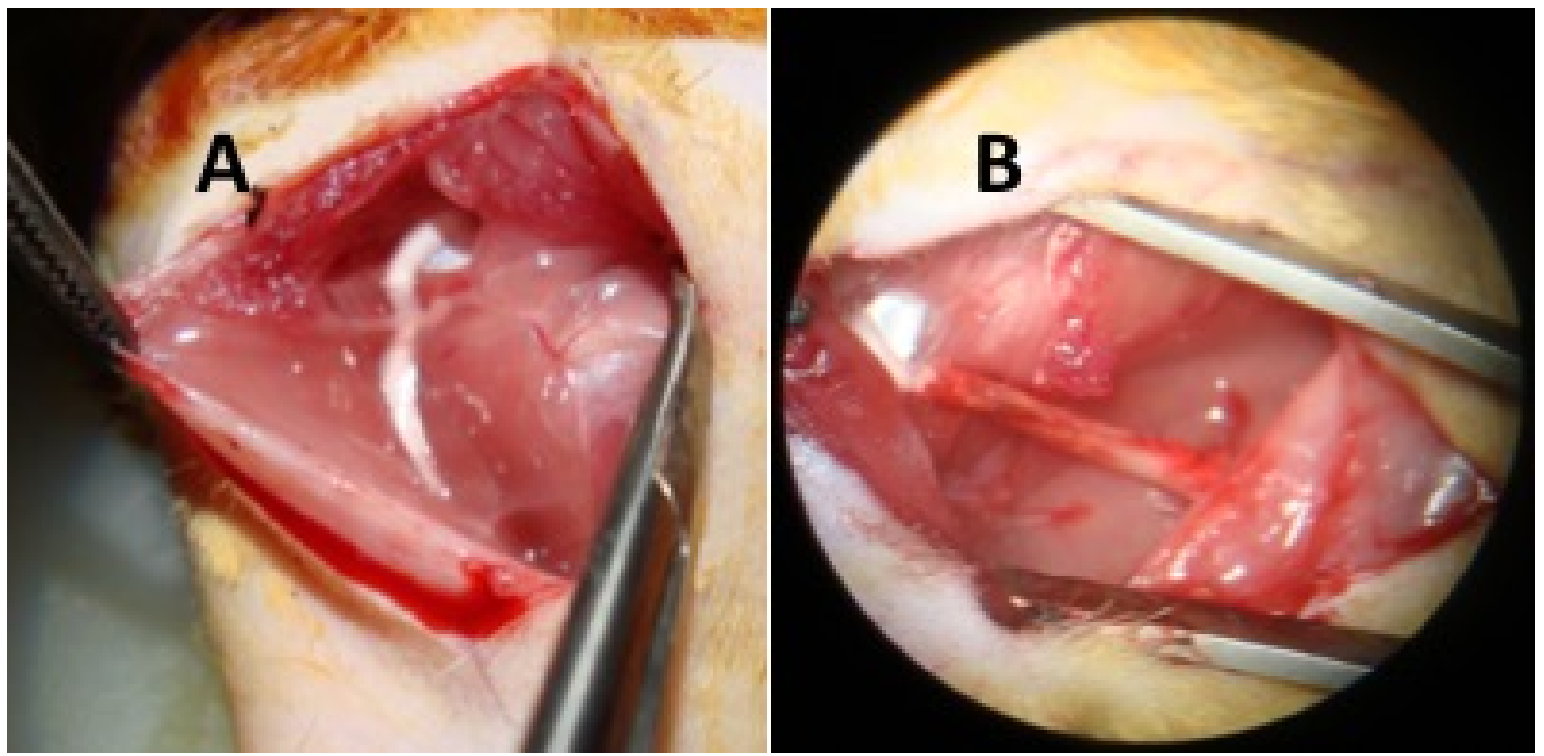

Figure 1. Figure 1. Right perioneal nerve flament of rats were opened (A), a $10 \mathrm{~mm}$ long section was removed and the PHBV conduits were placed (B).

were sacrificed at 17th week after surgery. As blood was taken from the inferior vena cava using heparinized syringe, the liver and surrounding tissue of PHBV conduit (muscle) were removed immediately and blood along with tissue samples were stored at - 80 ㄷ $\mathrm{Cuntil}$ the measurement of biochemical parameters.

\section{Biochemical Assays}

MDA levels were determined according to the method of Yoshioka et al. [13]. In this method, $250 \mu \mathrm{l}$ of serum or tissue homogenate, $1250 \mu$ of TCA (20\%), $500 \mu$ l of TBA $(0.67 \%)$ were mixed and heated at 95 ㄷ for $30 \mathrm{mi}-$ nutes. After it was cooled at room temperature, $2000 \mu \mathrm{l}$ of $n$-butanol was added to each sample and centrifuged at $3000 \mathrm{rpm}$ for 5 minutes. The intensity of pink/red color of the final product was determined at $532 \mathrm{~nm}$.

Determination of AOPPs was based on spectrophotometric detection method of Witko-Sarsat et al. [4]. Briefly, $200 \mu$ of plasma or tissue homogenate (diluted 1:5 with phosphate-buffered saline), $200 \mu$ of chloramine $T(0-100 \mu \mathrm{mol} / \mathrm{L}$, for calibration) and $200 \mu \mathrm{l}$ of PBS (blank) were applied on a microliter plate. $10 \mu$ of $1.16 \mathrm{M}$ potassium iodide and $20 \mu \mathrm{l}$ of acetic acid were added and the absorbance at $340 \mathrm{~nm}$ was measured immediately.

SOD (E.C. 1.15.1.1) activity assays were performed based on Sun et al.'s method [14]. $2.9 \mathrm{ml}$ of reaction mixture $(3 \mathrm{mmol} / \mathrm{L}$ xanthine, $150 \mu \mathrm{mol} / \mathrm{L} \mathrm{NBT}, 400 \mathrm{mmol} / \mathrm{L}$
$\mathrm{Na}_{2} \mathrm{CO}_{3}$ and $1 \mathrm{~g} / \mathrm{L} \mathrm{BSA}$ ), $50 \mu \mathrm{l}$ of sample and $50 \mu \mathrm{l}$ of xanthine oxidase were mixed and incubated at room temperature for 20 minutes. After the mixture was incubated, $1 \mathrm{ml}$ of $0.8 \mathrm{mM} \mathrm{CuCl}_{2}$ was applied and monitored spectrophotometrically at $560 \mathrm{~nm}$. One unit of SOD was defined as the amount of protein leading 50\% inhibition of the rate of NBT reduction.

The spectrophotometric method of Sedlak and Lindsay [15] was used to determine the blood sample and tissue's GSH contents. 10\% trichloroacetic acid was added into samples, mixed and allowed to stand for five minutes in order to measure the glutathione levels. Next, the samples were centrifuged for five minutes at $3000 \mathrm{rpm}$. After all, $0.5 \mathrm{ml}$ of the clear protein-free supernatant, $2 \mathrm{ml}$ of Tris-EDTA $(0.2 \mathrm{M}, \mathrm{pH}=8.9)$ and $0.1 \mathrm{ml}$

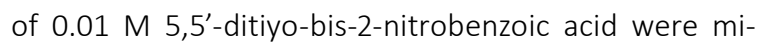
xed. Final product was incubated at room temperature for 10 minutes and monitored at $412 \mathrm{~nm}$.

The protein measurements process were carried out based on Lowry et al.'s method [16].

\section{Statistical Analysis}

Statistical analysis was performed using SPSS 16.0. Data are expressed as means \pm standard deviations (SD) of a representative of each group. ANOVA was used to determine which groups differed from one another. Scheffé test was used if mean differences were significant in ANOVA proofing significance difference of $p<0.05$. 


\section{RESULTS and DISCUSSION}

Over the last 30 years, nanomaterials have been widely applied in various medical fields [17]. Shin et al. [18] and Martin et al. [19] point out tissue engineering and regenerative medicine prepare a ground for alternative applications to restore or replace lost tissues by biomaterial. Some researchers like Deng et al. [20] have reported the damage of biomolecule due to the interaction between biomaterial and biomolecule such as protein, DNA and lipid. Singh and Ramarao [21] and Cupaioli et al. [22] have also revealed that the inhibition of some molecular pathways, free radical generation, damage of organelles, neurodegeration and cell death has been resulted from the interaction of nanoparticles with neural subcellular components. As biomaterial-induced oxidative stress can be regarded as one of the major cause of implant failure, there is a need for detailed studies for the sake of the biocompatibility of nanomaterials [23].

Excessive ROS formation can cause deleterious effects such as protein oxidation, lipid denaturation/peroxidation and structural alteration of DNA [24]. Superoxide dismutase (SOD) is a free radical scavenger acting as a major endogenous enzymatic cellular defender. According to Reddy et al. [25], SOD inhibits several cellular cascades leading to apoptotic cell death, as well. In our study, compared to control groups, MDA, AOPP, GSH levels and SOD activities in all graft groups showed a remarkable increase.

Based on findings, muscle, liver and serum MDA levels were revealed markedly high in grafted animals group. As shown in Figure 2, lipid peroxidation formation increased nearly threefold in muscle compared with control group valued $(p<0.001)$. Besides this, graft groups AOPP showed a significant difference for muscle, serum and liver respectively at $p<0.005, p<0.001$ and $p<$ 0.005 (Figure 3). While glutathione did not show significant statistical difference in both tissue groups, serum levels illustrated in Figure 4 soared dramatically in PHBV graft group valued $p<0.001$. Figure 5 depicts liver and muscle SOD activities did not show remarkable statistical deference, but enzyme activities of serum in PHBV group were significantly higher than the control group ones valued $(p<0.001)$. In one study, Gangwar et al. [26] created full thickness skin wounds in rats. The wounds for group 1 were dressed, defects for group 2 were repaired with acellular dermal matrix (ADM). ADM used as a bioscaffold for the repair of defect were se- eded with primary chicken embryo fibroblasts [P-CEF (3-D ADM,)] in group 3. Days 3, 7 and 14, MDA levels showed an increase in all groups. While GSH values witnessed an increase in groups 2 and 3 on day 7, higher SOD activities were recorded up to day 14 and 7 in groups 1 and 2, respectively. Consistent with significant higher catalase levels being observed on day 7 in all groups, the results of our study showed the similar effects on tissues and serums. Tissue injury and oxidative stress might be the reason of significant high MDA and AOPP concentrations in PHBV-conduit groups. Furthermore, GSH and SOD high values might be resulted from oxidative stress which reduces the antioxidant molecules in tissues of graft groups. Our reseach also aimed to find out whether oxidant-antioxidant system imbalance due to possible PHBV-conduit-induced causes endures for long period of time or not. To this aim, rats were sacrificed at $17^{\text {th }}$ week and it was determined that lipid peroxidation and protein oxidation still continues at $17^{\text {th }}$ week, as well. The reason might be related to effects of reactions initiated by degradation products of PHBVconduit or inflammation. Therefore, the aftermath of the degradation products of PHBV in the cells must be investigated exhaustively. In another study, Xiong et al. [27] investigated PLGA nanoparticles in three different sizes in terms of viability, ROS formation, mitochondrial depolarization, integrity of plasma membrane, intracellular calcium influx and cytokine release. Although PLGA nanoparticles did not trigger lethal toxicity significantly up to $300 \mu \mathrm{g} / \mathrm{ml}$ a concentration, TNF- $\alpha$ release after PLGA nanoparticles' post-stimulation could be an important value in clinical applications particularly PLGA ability in protein adsorption process for cytotoxicity. As Cartiera et al. [28] determined that the PLGA nanoparticles exist in lysosomal compartment, Feng et al. [29] revealed that polymeric nanoparticle degradation products can cause lysosome dysfunction. Furthermore, mitochondrial dysfunction as a result of interaction of polymeric nanoparticle with mitochondria has been reported. Polymeric nanoparticles or their degradation products can accumulate in the mitochondria which can damage membranes and respiratory chain and thereby, disrupted electron transport chain induces the excessive ROS production [30-32]. Parallel to these studies, our study reveals PHBV-conduit may cause the similar intracellular processes. 


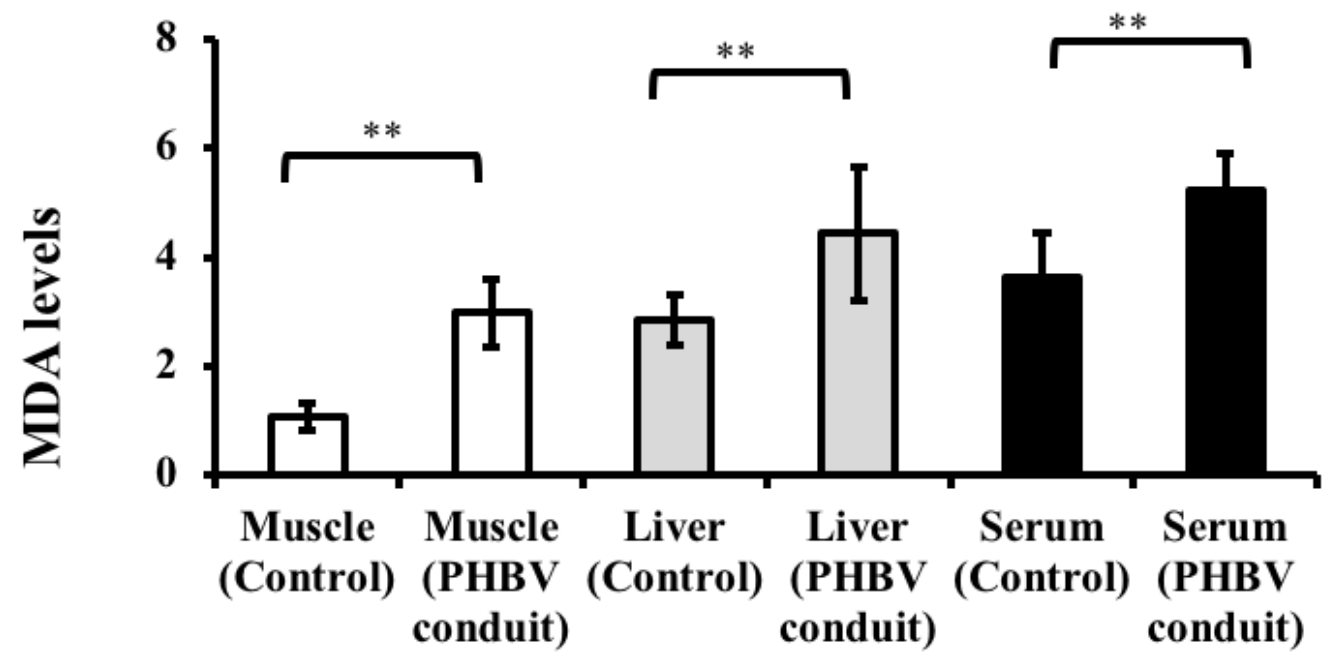

Figure 2. MDA levels of control and graft groups (surrounding tissues of conduits (muscles), livers and blood samples) in rats. Statistically significant difference was observed when control groups were compared to graft groups, ${ }^{* *} \mathrm{P}<0.005$.

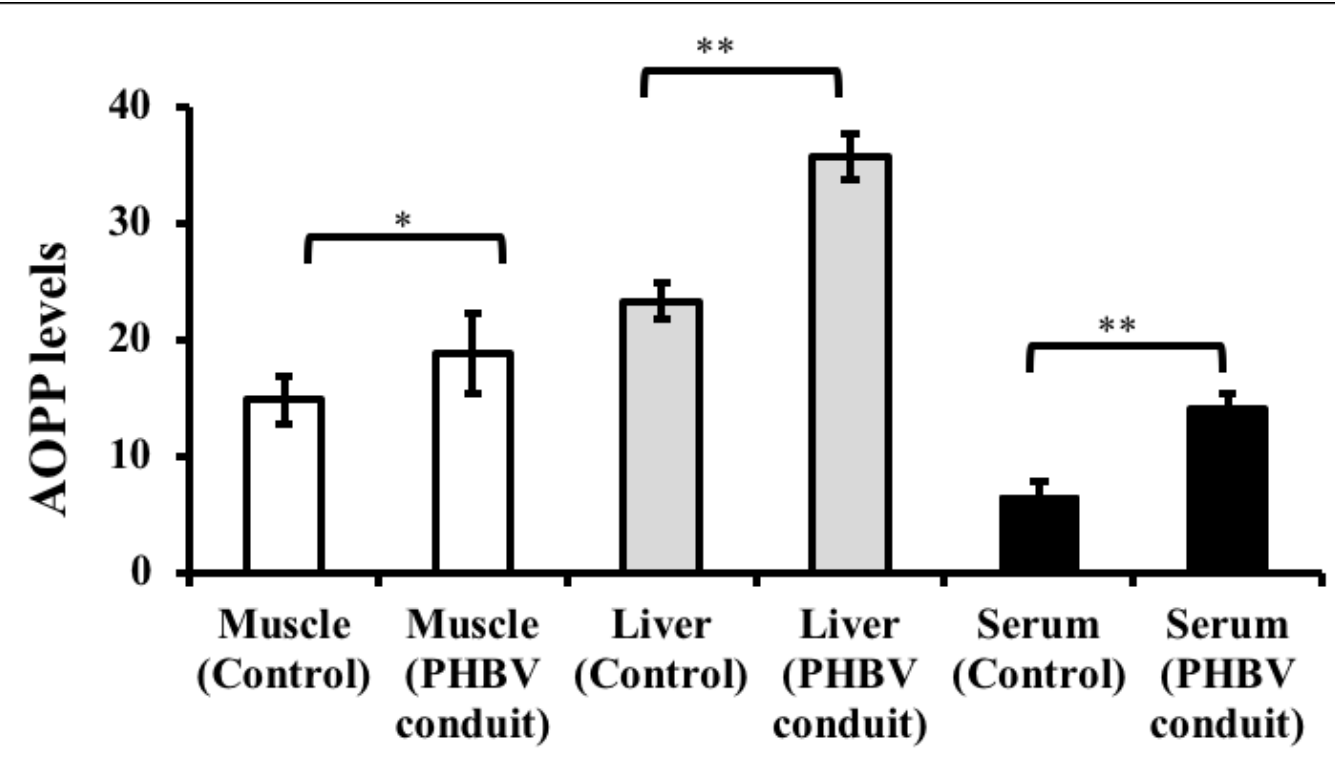

Figure 3. MAOPP levels in all groups, $* P<0.001 ; * *<0.005$. 


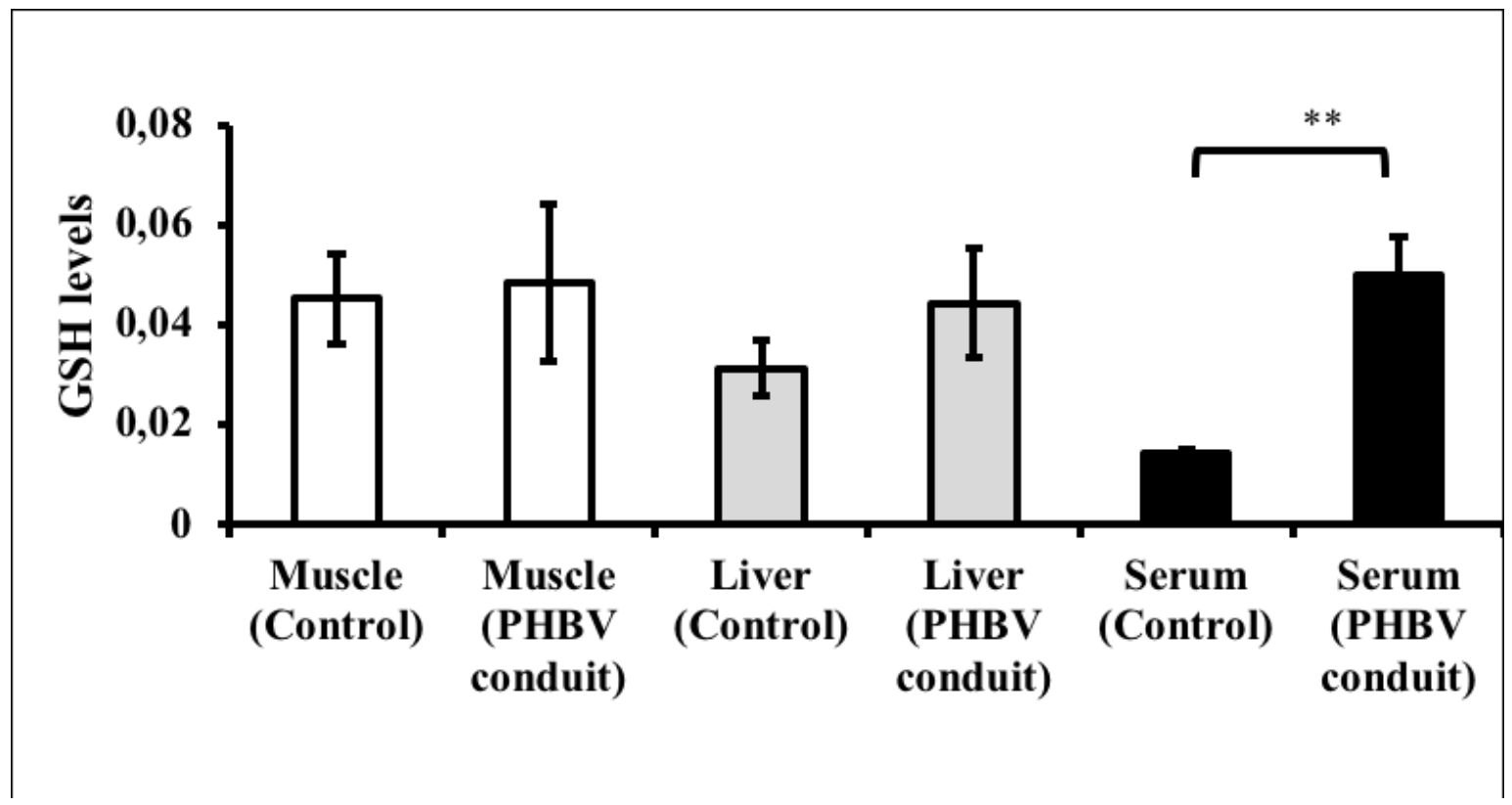

Figure 4. The results of GSH levels in control and graft groups, ${ }^{* *} \mathrm{P}<0.005$.

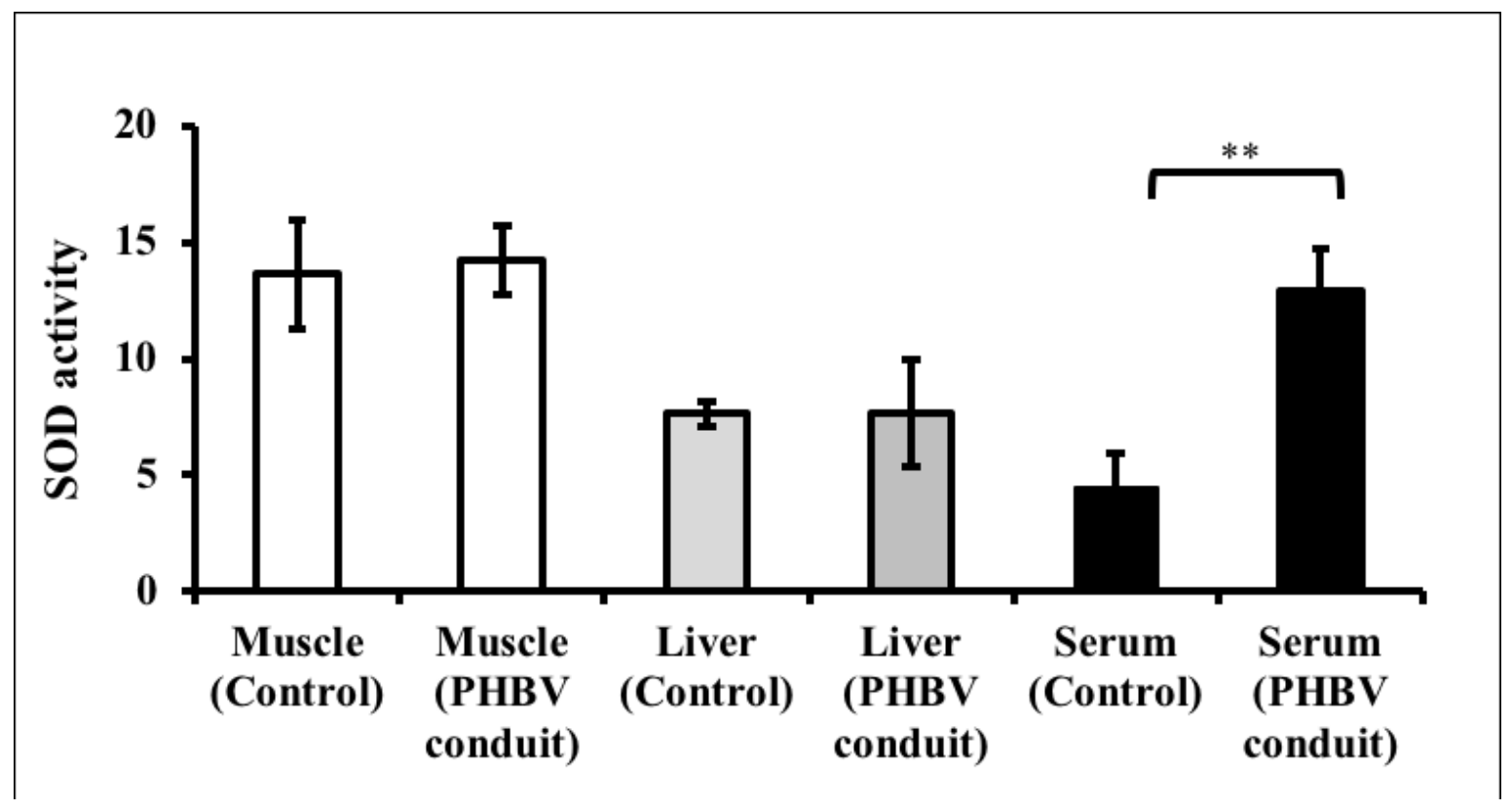

Figure 5. Superoxide dismutase activities of control and graft groups, ${ }^{* *} \mathrm{P}<0.005$. 
The accumulation of polymer degradation products brings about the ROS generation. Indeed, increased ROS levels are the cause of toxicity for many of biodegradable materials $[11,33]$. There has been no experimental research to examine the effect of PHBV-conduit used for axonal regeneration on possible oxidative stress. It is based on our study that protein and lipid structures appear obviously are damaged while it should be noted that the cellular mechanism of PHBV-graftinduced stress is still unknown. When a biomaterial induces an inflammatory response, a variety of cytokines are released by leukocytes and observed reactive oxygen species formation. Some studies have revealed the stimulation of ROS and TNF- $\alpha$ production in macrophages by polyester nanoparticles. The nanoparticles prepared using PLGA, PCL and DL-PLA stimulate the ROS increasingly [34-36]. As Serrano et al [37], have shown PCL induces transitory and significant oxidative stress in L929 fibroblasts. Also, Liu et al. [11] have demonstrated polymeric implants lead to three-fold stable increase in ROS production in surgical zones over a four week timeframe. Therefore, polymeric nanoparticles/ scaffolds or their degradation products can give rise to inflammation, excessive ROS generation, devastation of cellular redox potential, suppression of antioxidant defense systems. This study has revealed the alterations of redox imbalance and cellular functions might have been due to the interaction between PHBV-conduit and perioneal neuron. Considering the changes and the increase of MDA and AOPP levels in conduit groups look meaningful. Furthermore, ROS generation triggering oxidative stress in cells might have led to significant MDA and AOPP formation. Halamoda Kenzaoui et al.[38] have shown the oxidative stress and ROS production in cells exposed to NP and indicated NP's negative effects on cellular functions. Our findings were consistent with Halamoda Kenzaoui et al. [38] study as our study revealed PHBV-graft-induced oxidative stress in surrounding tissues of conduits (muscles), livers and blood samples. The rise of GSH levels and SOD activities scavenging the free radicals caused by PHBV was also revealed in the study. That is why the results show the possibility of defense mechanism in conduit-treated tissues.

\section{CONCLUSION}

Finally, the results gives an account that PHBV conduit used for perioneal nerve regeneration induces the ROS generation with the probability of degradation products permeating to the circulation and reaching to liver. The concentrations of malondialdehyde and advanced oxidation protein products markedly rise in surrounding tissue of graft (muscle), liver and blood. Additionally, the ROS scavengers SOD and glutathione to cope with PHBV conduit-induced oxidative stress blocking oxidative alterations. Although PHBV is thought to be nontoxic, the use of PHBV-conduit for axonal regeneration may cause oxidative stress. Beside to, the interaction of degradation products of PHBV-conduit with intracellular organelles may lead to the ROS generation. Therefore, better understanding interaction of scaffolds/ polymeric nanoparticles mechanisms is crucial as the use of tissue grafts. However, it should be kept in mind that tissue grafts may trigger oxidative stress.

\section{References}

1. J.L. Gilmore, X. Yi, L. Quan, A.V. Kabanov, Novel nanomaterials for clinical neuroscience, J. Neuroimmune Pharmacol., 3 (2008) 83-94.

2. H. Sies, Oxidative stress: From basic research to clinical application, Am. J. Med., 91 (1991) 31-38.

3. B. Halliwell, J.M.C. Gutteridge, Free radicals in biology and medicine, Development, 134 (2007) 635-646.

4. V. Witko-Sarsat, M. Friedlander, T.N. Khoa, C. CapeillèreBlandin, A.T. Nguyen, S. Canteloup, J.M. Dayer, P. Jungers, T. Drüeke, B. Descamps-Latscha, Advanced oxidation protein products as novel mediators of inflammation and monocyte activation in chronic renal failure, J. Immunol., 161, (1998) 2524-2532

5. K. Aquilano, S. Baldelli, B. Pagliei, S.M. Cannata, G. Rotilio, M.R. Ciriolo, p53 Orchestrates the PGC-1 $\alpha$-mediated antioxidant response upon mild redox and metabolic imbalance, Antioxid. Redox Signal., 18 (2012) 386-399.

6. E. Barone, G. Cenini, F. Di Domenico, T. Noel, C. Wang, M. Perluigi, DK. St Clair, D.A. Butterfield, Basal brain oxidative and nitrative stress levels are finely regulated by the interplay between superoxide dismutase 2 and p53, J. Neurosci. Res., 93 (2015) 1728-1739.

7. P.A. Mouthuy, S.J.B. Snelling, S.G. Dakin, L. Milković, A.Č. Gašparović, A.J. Carr, N. Žarković, Biocompatibility of implantable materials: an oxidative stress viewpoint, Biomaterials, 109 (2016) 55-68.

8. W. Tao, D. Pan, Z. Gong, X. Peng, Nanoporous platinum electrode grown on anodic aluminum oxide membrane: Fabrication, characterization, electrocatalytic activity toward reactive oxygen and nitrogen species, Anal. Chim. Acta, 1035 (2018) 44-50.

9. W.W. Jiang, S.H. Su, R.C. Eberhart, L. Tang, Phagocyte responses to degradable polymers, J. Biomed. Mater. Res. A, 82 (2007) 492-497.

10. H.H. Chang, M.K. Guo, F.H. Kasten, M.C. Chang, G.F. Huang, Y.L. Wang, R.S. Wang, J.H. Jeng, Stimulation of glutathione depletion, ROS production and cell cycle arrest of dental pulp cells and gingival epithelial cells by HEMA, Biomaterials, 26 (2005) 745-753.

11. W.F. Liu, M. Ma, K.M. Bratlie, T.T. Dang, R. Langer, D.G. Anderson, Real-time in vivo detection of biomaterial-induced reactive oxygen species, Biomaterials, 32 (2011) 1796-1801. 
12. M. Demirbilek, M. Sakar, Z. Karahaliloğlu, E. Erdal, E. Yalçın, G. Bozkurt, P. Korkusuz, E. Bilgiç, Ç.M. Temuçin, E.B. Denkbaş, Aligned bacterial PHBV nanofibrous conduit for peripheral nerve regeneration, Artif. Cell. Nanomed. Biotechnol., 43 (2015) 243-251.

13. T. Yoshioka, K. Kawada, T. Shimada, M. Mori, Lipid peroxidation in maternal and cord blood and protective mechanism against activated-oxygen toxicity in the blood, Am. J. Obstet. Gynecol., 135 (1979) 372-376.

14. Y. Sun, L.W. Oberley, Y. Li, A simple method for clinical assay of superoxide dismutase, Clin. Chem., 34 (1988) 497-500.

15. J. Sedlak, R.H. Lindsay, Estimation of total, protein-bound, and nonprotein sulfhydryl groups in tissue with Ellman's reagent, Anal. Biochem., 25 (1968) 192-205.

16. O.H. Lowry, N.J. Rosebrough, A.L. Farr, R.J. Randall, Protein measurements with the folin phenol reagent, J. Biol. Chem. 193 (1951) 265-275.

17. A. Schröfel, G. Kratošová, I. Šafařík, M. Šafaříková, I. Raška,L.M. Shor, Applications of biosynthesized metallic nanoparticles - A review, Acta Biomater., 10 (2014) 4023 4042.

18. H. Shin, S. So, A.G. Mikos, Biomimetic materials for tissue engineering, Biomaterials, 24 (2003) 4353-4364.

19. J.R. Martin, M.K. Gupta, J.M. Page, F. Yu, J.M. Davidson, S.A. Guelcher, C.L. Duvall, A porous tissue engineering scaffold selectively degraded by cell-generated oxygen species, Biomaterials, 35 (2014) 3766-3776.

20. Z.J. Deng, M.T. Liang, M. Monteiro, I. Toth, R.F. Minchin, Nanoparticle-induced unfolding of fibrinogen promotes Mac-1 receptor activation and inflammation, Nat. Nanotechnol., 6 (2011) 39-44.

21. R.P. Singh, P. Ramarao, Accumulated polymer degradation products as effector molecules in cytotoxicity of polymeric nanoparticles, Toxicol. Sci., 136 (2013) 131-143.

22. F.A. Cupaioli, F.A. Zucca, D. Boraschi, L. Zecca, Engineered nanoparticles. How brain friendly is this new guest?, Prog. Neurobiol., 119-120 (2014) 20-38.

23. J.D. De Queiroz, A.M. Leal, M. Terada, L.F. Agnez-Lima, I. Costa, N.C. Pinto, S.R. Mediros, Surface modification by argon plasma treatment improves antioxidant defense ability of CHO-k1 cells on titanium surfaces, Toxicol. In Vitro, 28 (2014) 381-387.

24. K. Brieger, S. Schiavone, F.J. Miller, K.H. Krause, Reactive oxygen species: from health to disease, Swiss Med. Wkly., 142 (2012) 13659.

25. M.K. Reddy, L. Wu, W. Kou, A. Ghorpade, V. Labhasetwar, Superoxide dismutase-loaded PLGA nanoparticles protect cultured huöam neurons under oxidative stress, Apply. Biochem. Biotechnol., 151 (2008) 565-577.
26. A.K. Gangwar, N. Kumar, S.D. Khangembam, V. Kumar, R. Singh, Primary chicken embryo fibroblasts seeded acellular dermal matrix (3-D ADM) improve regeneration of full thickness skin wounds in rats, Tissue Cell., 47 (2015) 311-322.

27. S. Xiong, S. George, H. Yu, R. Damoiseaux, B. France, K.W. $\mathrm{Ng}$, J.S. Loo, Size influences the cytotoxicity of poly (lacticco-glycolic acid) (PLGA) and titanium dioxide (TiO(2)) nanoparticles, Arch. Toxicol., 87 (2013) 1075-1086.

28. M.S. Cartiera, K.M. Johnson, V. Rajendran, M.J. Caplan, W.M. Saltzman, The uptake and intracellular fate of PLGA nanoparticles in epithelial cells, Biomaterials, 30 (2009) 2790-2798

29. X. Feng, A. Chen, Y. Zhang, J. Wang, L. Shao, L. Wei, Central nervous system toxicity of metallic nanoparticles, Int. J. Nanomedicine, 10 (2015) 4321-4340.

30. J. Lee, S. Giordano, J. Zhang, Autophagy, mitochondria and oxidative stress: cross-talk and redox signalling, Biochem. J., 441 (2012) 523-540.

31. Y.H. Luo, S.B. Wu, Y.H. Wei, Y.C. Chen, M.H. Tsai, C.C. Ho, S.Y. Lin, C.S. Yang, P. Lin, Cadmium-based quantum dot induced autophagy formation for cell survival via oxidative stress, Chem. Res. Toxicol., 26 (2013) 662-673.

32. K.N. Yu, T.J. Yoon, A. Minai-Tehrani, J.E. Kim, S.J. Park, M.S. Jeong, S.W. Ha, J.K. Lee, J.S. Kim, M.H. Cho, Zinc oxide nanoparticle induced autophagic cell death and mitochondrial damage via reactive oxygen species generation, Toxicol. In Vitro, 27 (2013) 1187-1195.

33. K. Fu, D.W. Pack, A.M. Klibanov, R. Langer, Visual evidence of acidic environment within degrading poly(lactic-co-glycolic acid) (PLGA) microspheres, Pharm. Res., 17 (2000) 100-106.

34. T.M. Allen, D.R. Mumbengegwi, G.J. Charrois, Anti-CD19 targeted liposomal doxorubicin improves the therapeutic efficacy in murine B-cell lymphoma and ameliorates the toxicity of liposomes with varying drug release rates, Clin. Cancer Res., 11 (2005) 3567-3573.

35. G.J. Charrois, T.M. Allen, Drug release rate influences the pharmacokinetics, biodistribution, therapeutic activity, and toxicity of pegylated liposomal doxorubicin formulations in murine breast cancer, Biochim. Biophys. Acta, 1663 (2004) 167-177.

36. S. Xiong, H. Li, B. Yu, J. Wu, R.J. Lee, Triggering liposomal drug release with a lysosomotropic agent, J. Pharm. Sci., 99 (2010) 5011-5018.

37. M.C. Serrano, R. Pagani, J. Peña, M.T. Portolés MT, Transitory oxidative stress in $\mathrm{L929}$ fibroblasts cultured on poly(epsiloncaprolactone) films, Biomaterials, 26 (2005) 5827-5834.

38. B. Halamdo Kenzaoui, C. Chapuis Bernasconi, S. Guney-Ayra, L. Juillerat-Jeanneret, Induction of oxidative stress, Iysosome activation and autophagy by nanoparticles in human brainderived endothelial cells, Biochem., 441 (2012) 813-821. 